\title{
INTEGRASI BAHAN AJAR KEWIRAUSAHAAN BIDANG PRODUKTIF BANGUNAN
}

\author{
V. Lilik Hariyanto \\ Jurusan Pendidikan Teknik Sipil dan Perencanaan, \\ Fakultas Teknik Universitas Negeri Yogyakarta. \\ Vlilik_hy@yahoo.co.id
}

\begin{abstract}
Abstrak: Integrasi Bahan Ajar Kewirausahaan Bidang Produktif Bangunan. Lulusan Sekolah Menengah Kejuruan diharapkan: (1) bekerja pada bidang pekerjaan yang sesuai dengan bidang kejuruannya, (2) melanjutkan pendidikan ke tingkat yang lebih tinggi, dan (3) berwirausaha. SMK Bangunan harus mampu membuat lulusannya menciptakan laangan kerja. Hal ini dapat dicapai salah satunya dengan mengintegrasikan kewirausahaan ke dalam pembelajaran mata pelajaran produktif. Ada tiga rumusan masalah, yaitu: (1) bagaimana mengimplementasikan standard kometensi dan kompetensi dasar, silabus kerja batu? (2) bagaimana integrasi mata pelajaran kewirausahaan ke dalam mata pelajaran produktif? (3) bagaimana pengembangan RPPnya? Langkah-langkah integrasi meliputi: (1) identifikasi elemen kewirausahaan, (2) identifikasi pengetahuan, keterampilan, sikap, dan nilai, (3) mengklasifikasi di dalam bentuk topic dan tema, (4) identifikasi kompetensi dasar, (5) menemukan strategi belajar, (6) revisi, (7) uji coba. Kesimpulan: (1) mata pelajaran kewirausahaan dan mata pelajaran produktif untuk praktik kerja konstruksi dan beton dapat diintegrasikan, (2) Hasil integrasi dapat meningkatkan kesiapan siswa, (3) (2) Product integration can foster entrepreneurship student readiness.
\end{abstract}

Kata kunci: bahan ajar, teknik bangunan, integrasi

\section{ENTREPRENEURSHIP LEARNING MATERIAL INTEGRATION INTO VOCATIONAL SUBJECTS IN BUILDING TECHNOLOGY STUDY PROGRAM}

\begin{abstract}
Entrepreurship Learning Material Integration into Vocational Subjects in Building Technology Study Program. Vocational School graduates should be able to: (1) work in the vocational field in accordance with the disciplines learned, (2) pursue at higher levels of education, and (3) Entrepreneurial. SMK Building should be able to make the graduates able to find a job or to create jobs by him/herself.". Three problems are formulated, namely: (1) how the implementation of standards of competence and basic competencies (SK-KD), syllabus of vocational subjects of masonry and concrete work? (2) How is the integration of entrepreneurial subjects in the subject field of masonry and concrete productive? (3) How is the development of Learning Implementation Plan (RPP). Integration steps: (1) to identify elements of entrepreneurship (2) to identify knowledge, skills, attitudes and values (3) classify in the form of topic / theme, (4) to identify the basic competencies (5) creating a learning strategy, (6) Revised, (7) trial. Conclusions: (1) entrepreneurship subjects with subjects productive field stone and concrete work practices can be integrated, (2) Product integration can foster entrepreneurship student readiness.
\end{abstract}

Keywords: entrepreneurship, stone and concrete work practices, integration of learning.

\section{PENDAHULUAN}

Rumusan Misi Pendidikan Nasional menurut Undang-Undang Nomor 20 yaitu: (1) Mengupayakan perluasan dan pemerataan kesempatan memperoleh pendidikan yang bermutu bagi seluruh rakyat Indonesia, (2) Membantu dan memfasilitasi pengembangan potensi anak bangsa secara utuh sejak usia dini 
sampai akhir hayat dalam rangka mewujudkan masyarakat belajar, (3) Meningkatkan kesiapan masukan dan kualitas proses pendidikan untuk mengoptimalkan pembentukan kepribadian yang bermoral, (4) Meningkatkan profesionalisme dan akuntabilitas lembaga pendidikan dan pengelolanya sebagai pusat pembudayaan ilmu pengetahuan, keterampilan, pengalaman, sikap, dan nilai berdasarkan standar nasional dan global, dan (5) Memberdayakan peran serta masyarakat dalam penyelenggaraan pendidikan berdasarkan prinsip otonomi dalam konteks Negara Kesatuan Republik Indonesia. Oleh karena itu peranan pendidikan menjadi sangat sentral.

Di sisi lain, era globalisasi saat ini membawa dampak ganda pada setiap negara, termasuk Indonesia. Di satu sisi membawa iklim yang semakin terbuka untuk bekerjasama saling melengkapi demi kepentingan yang saling menguntungkan bagi pihak yang bekerjasama. Namun di sisi lain, era ini melahirkan persaingan yang semakin ketat dalam berbagai bidang. Era globalisasi menjanjikan masa depan yang cerah bagi negara yang sungguh-sungguh mempersiapkan diri untuk menghadapi proses globalisasi. Hal ini didukung dengan adanya pasar bebas Asean yaitu Asean Free Trade Area (AFTA) dan Asean Free Labour Area (AFLA) tahun 2003. Suatu kawasan yang telah melahirkan beberapa negara industri maju, tetapi juga beberapa negara yang tertelan menjadi korban kemajuan negara tetangga. Kenyataan tersebut merupakan tuntutan untuk menyiapkan SDM dengan standar kompetensi dan keahlian sebagai pelaku ekonomi, sehingga unggul bersaing di pasar domestik maupun internasional. Sementara, tanggung jawab lembaga pendidikan Di Indonesia dalam memasuki era globalisasi adalah mempersiapkan lulusan untuk menghadapi tantangan-tantangan dalam masyarakat yang sangat cepat perubahannya. Tantangan yang dihadapi para lulusan adalah menjadi pekerja yang memiliki keterampilan dan keahlian dalam Era Asean Free Trade Area (AFTA) dan Asean Free Labor Area (AFLA). Integrasi perekonomian tingkat lokal, regional, nasional dengan perekonomian global seperti AFTA, APEC, WTO/GATT memang tidak bisa dihindari. Suka atau tidak suka, mau atau tidak mau, kenyataan integrasi perekonomian dunia ini memang harus dihadapi.

Pengembangan kesiapan berwirausaha Di Indonesia menjadi suatu kebutuhan yang mendesak. Kenyataannya, wirausaha mandiri seolah makin merebak ke berbagai daerah. Tidak sedikit mahasiswa ataupun pelajar yang tak lagi malu dan ragu untuk memulai usaha, meski awalnya terbilang kelas kecil-kecilan. Seminar-seminar entrepreneurship yang makin marak tak pelak juga turut mengkondisikan iklim mendorong tumbuh kembangnya wirausaha mandiri tersebut. Menariknya, lembaga pendidikan sebagai kawah candradimukanya pebelajar pun kini mulai menaruh perhatian terhadap upaya mendorong munculnya jiwa-jiwa enterpeneurship di kalangan pebelajar. Salah satu potensi yang mesti digarap, adalah dunia sekolah/kampus. Tak terhitung SDM yang lahir dari tempat ini, tapi tak semua beruntung. Kalau mau jujur, sebagian besar lulusan saat lulus nanti masih berorientasi pada bagaimana mencari kerja. Sangat sedikit lulusan yang punya tekad dan keinginan kuat untuk berbisnis, menciptakan 
lapangan kerja. (Rhenald Khasali, 2010). Lebih lanjut Ia mengatakan bahwa upaya mendorong wirausaha mandiri sendiri tak lepas dari program pemerintah dalam mendorong pertumbuhan ekonomi baik lokal maupun nasional. Idealnya, jumlah wirausaha mandiri minimal adalah 2 persen dari total populasi. Sementara hingga 2009 kemarin, persentase wirausaha mandiri masih berada di angka 0,18 persen. Artinya masih jauh di bawah standar ideal. Hal inilah yang akhirnya mendorong pemerintah bersama kalangan swasta berupaya menggalakkan program industri kreatif.

Dari kalangan pendidikan pun, program kewirausahaan bagi pebelajar terus dibenahi. Pemerintah telah mengeluarkan Instruksi Presiden R.I. Nomor 4, tahun 1995 tentang "gerakan nasional memasyarakatkan dan membudayakan kewirausahaan". Kemudian Inpres ini ditindaklanjuti oleh Depdiknas, dengan diluncurkannya program pengembangan kewirausahaan dalam bentuk paket-paket pendidikan dan kegiatan bagi siswa SMK dan mahasiswa. Program ini merupakan bentuk kepedulian pemerintah dan Depdiknas terhadap masih tingginya tingkat pengangguran dikalangan terdidik khususnya lulusan SMK dan perguruan tinggi serta dalam rangka menjawab tantangan global. Pemerintah melalui Departemen Koperasi dan UKM juga telah mencanangkan program "Getuk Nasional" (Gerakan Tunas Kewirausahaan Nasional) untuk pelajar SMA dan mahasiswa. Program ini merupakan gerakan penanaman jiwa kewirausahaan secara dini kepada siswa-siswa khususnya dan masyarakat pemula yang akan melakukan kegiatan wirausaha (Suryadharma Ali dalam Wiedy Murtini, 2009:7).
Pada tahun ajaran baru 2010-2011 ini, kurikulum berbasis kewirausahaan rencananya akan mulai dijalankan di sekolah-sekolah, (Muhamad Nuh, 2009). Sejalan dengan itu, hingga tahun 2008 telah dikembangkan sebanyak 100 SMA dan 341 SMK berbasis keunggulan lokal. Rasio jumlah siswa SMK:SMA dari tahun ke tahun juga terus meningkat dari 30:70 pada tahun 2004 menjadi 49:51 menurut perhitungan sementara pada akhir bulan September 2009, (Rencana Strategis Kementerian Pendidikan Nasional 2010-2014: 9). Menteri Pendidikan Nasional Muhammad Nuh menyatakan pentingnya pengembangan keingintahuan dan kemampuan berpikir secara fleksibel, kreatif, dan inovatif dalam penerapan kurikulum berbasis kewirausahaan. Tujuan ini positif karena definisinya tidak bersifat sempit semata-mata untuk mencetak lulusan siap kerja saja, namun juga memiliki kemampuan untuk menyelesaikan masalah, beradaptasi, dan dapat menciptakan lapangan kerja. Kemampuan ini diharapkan akan meningkatkan keunggulan sumber daya manusia Indonesia untuk bersaing dalam kancah masyarakat dunia yang berbasis pengetahuan dan kreatifitas. Walaupun demikian, ada dua catatan penting, yaitu: (1) Keterbatasan visi pendidikan berbasis kewirausahaan dan kejuruan,

Kesalahkaprahan strategi yang terpaku pada perubahan bentuk dan kurikulum, bukan pada apakah dan bagaimana guru dapat mengembangkan kurikulum dan memperbaiki proses pembelajaran untuk mencapai hasil proses belajar mengajar yang diharapkan. (http://ruangjeda.blogspot.com/2010/02/pendidi kan kewirausahaan-smk.html). Selanjutnya dikatakan pula, kurikulum berbasis 
kewirausahaan, maupun pendidikan kejuruan bukanlah garansi bagi terjadinya pengembangan kemampuan berpikir. Namun proses pembelajaran yang tepatlah yang akan menumbuhkan kemampuan tersebut. Perubahan kurikulum yang tidak disertai dengan pembekalan peningkatan keterampilan guru dalam mengembangkan kurikulum dan proses pembelajaran niscaya akan sia-sia.

Arahan Presiden Republik Indonesia dengan tema Prioritas Bidang Pendidikan tahun 20092014 sebagai berikut: "Peningkatan akses pendidikan yang berkualitas, terjangkau, relevan, dan efisien menuju terangkatnya kesejahteraan hidup rakyat, kemandirian, keluhuran budi pekerti, dan karakter bangsa yang kuat. Pembangunan bidang pendidikan diarahkan demi tercapainya pertumbuhan ekonomi yang didukung keselarasan antara ketersediaan tenaga terdidik dengan kemampuan: (1) menciptakan lapangan kerja atau kewirausahaan dan (2) menjawab tantangan kebutuhan tenaga kerja saat ini. (http://www2.ilmci.com/?p=1294). Berkaitan dengan kewirausahaan Mendiknas mengatakan bahwa seorang entrepreneur bukan untuk memenuhi dirinya sendiri. Wirausaha, kata Mendiknas, pasti ada interaksi dengan masyarakat luar dan ada interaksi dengan dunia disiplin yang berbeda. Lebih lanjut dikatakan bahwa kebijakan pendidikan yang tertuang di dalam Rencana Strategis 5 tahun ke depan memberikan ruang untuk pendidikan yang mampu mendorong kewirausahaan. "Itu adalah sesuatu hasil introspeksi dan refleksi dari sekian panjang perjalanan dunia pendidikan Di Indonesia. Ternyata ada slot yang belum tergarap, sehingga sayang slot itu (kewirausahaan) kalau tidak digarap dengan baik,". Demikian pula Dirjen Mandikdasmen Depdiknas Suyanto melaporkan, berbagai penajaman program implementasi kewirausahaan di SMK agar seperti yang diprogramkan oleh Presiden yaitu tercapai kesinambungan relevansi antara pendidikan dengan dunia kerja. (http://www2.ilmci.com/?p=1312.

Program SMK merupakan program pendidikan menengah dengan tujuan mempersiapkan lulusan yang tidak melanjutkan ke jenjang pendidikan tinggi untuk lebih siap masuk dunia kerja. (Suyanto, 2009: 5). Artinya muara lulusan Sekolah Menengah Kejuruan (SMK) pada dasarnya mengarah pada: (1) Bekerja di bidang kejuruan yang sesuai dengan disiplin ilmu yang dipelajari ketika sekolah, (2) Melanjutkan pendidikan ke jenjang pendidikan yang lebih tinggi seperti perguruan tinggi, dan (3) Wirausaha.

Lulusan yang telah bekerja dan melanjutkan pendidikan ke jenjang yang lebih tinggi cenderung tidak banyak menimbulkan permasalahan yang harus ditangani oleh pemerintah dan lembaga yang terkait. Namun lulusan yang tidak bekerja dan tidak melanjutkan pendidikan ke jenjang yang lebih tinggi, bila dibiarkan akan memunculkan suatu permasalahan yang kompleks. Idealnya, mereka harus dapat berwirausaha setelah lulus dari SMK, karena mereka selama belajar di SMK dibekali dengan mata pelajaran produktif dan mata pelajaran kewirausahaan. Namun kenyataannya lulusan yang tidak bekerja dan melanjutkan pendidikan cenderung tidak dapat berwirausaha. 
Kenyataan ini, setelah ditelusuri ternyata disebabkan implementasi silabus mata pelajaran produktif dan mata pelajaran kewirausahaan di SMK berjalan secara sendiri-sendiri. Kedua mata pelajaran tersebut implementasinya tidak terintegrasi, padahal kedekatan karakteristik kedua mata pelajaran tersebut sangatlah dekat.

Siswa SMK Bangunan, khususnya jurusan kerja batu dan beton setelah lulus dari sekolah sangat terbuka lebar dalam berwirausaha, tetapi selama ini peluang tersebut belum tertangkap oleh mereka, karena belum terbinanya kesiapan untuk menjadi wirausahawan. Peluang untuk berwirausaha pada bidang ini sangat lebar, misalnya keterampilan dalam membuat ornamen bangunan yang berbahan dasar dari semen-pasir (paving-blok, Kon-blok, roster dll). Keterampilan ini sifatnya sangat praktis dan tidak memerlukan suatu aplikasi teknologi yang rumit dan tingkat tinggi. Oleh karenanya SMK Bangunan perlu menyadari akan hal ini, mestinya harus dapat menjadikan "lulusan dengan kemampuannya bagaimana mencari pekerjaan bergeser dengan berkat kemampuannya bagaimana menciptakan lapangan kerja”.

Berpijak dari uraian di atas, jelas bahwa penanaman kewirausahaan dalam menumbuhkan kesiapan untuk menjadi wirausahawan bagi siswa SMK Bangunan merupakan aspek penting dalam menghasilkan lulusan yang mampu menciptakan lapangan kerja (berwirausaha). Oleh karenanya diperlukan kajian, rumusan, dan implementasi pola-pola integrasi dalam model pembelajaran dengan berbagai strategi. Dalam tulisan ini terdapat tiga rumusan masalah yaitu: (1) Bagaimanakah pelaksanaan standar kompetensi dan kompetensi dasar (SK-KD) silabus bidang produktif konstruksi batu dan beton SMK
Bangunan di Daerah Istimewa Yogyakarta? (2) Bagaimanakah integrasi mata pelajaran kewirausahaan pada mata pelajaran bidang produktif konstruksi batu dan beton dalam pembelajaran di SMK Bangunan di Daerah Istimewa Yogyakarta? (3) Bagaimanakah pengembangan Rencana Pelaksanaan Pembelajaran (RPP) bidang Produktif konstruksi batu dan beton yang terintegrasi kewirausahaan?

\section{Ranah Integrasi Kewirausahaan-Bidang Produktif.}

Kewirausahaan berasal dari kata wira dan usaha. Wira, berarti pejuang, pahlawan, manusia unggul, teladan, berbudi luhur, gagah berani dan berwatak agung. Usaha, berarti perbuatan amal, bekerja, berbuat sesuatu. Jadi wirausaha dipandang dari segi etimologi adalah pejuang atau pahlawan yang berbuat sesuatu, (http://wirausahaumy.blogspot.com). diakses tanggal 9 Mei 2009). Kewirausahaan yang sering dikenal dengan sebutan entrepreneurship berasal dari Bahasa Perancis yang diterjemahkan secara harfiah adalah perantara, diartikan sebagai sikap dan perilaku mandiri yang mampu memadukan unsur cipta, rasa dan karsa serta karya atau mampu menggabungkan unsur kreativitas, tantangan, kerja keras dan kepuasan untuk mencapai prestasi maksimal, secara sederhana arti wirausahawan adalah orang yang berjiwa berani mengambil resiko untuk membuka usaha dalam berbagai kesempatan. Berjiwa berani mengambil resiko artinya bermental mandiri dan berani memulai usaha, tanpa diliputi rasa takut atau cemas sekalipun dalam kondisi tidak pasti. (Kasmir, 2007). Kewirausahaan menyangkut tiga dimensi penting (Erni Unggul, 1998), yakni: (a) inovasi, (b) pengambilan resiko dan (c) proaktif. Keinovatifan mengacu pada pengembangan 
produk, jasa atau proses yang unik. la meliputi upaya sadar untuk menciptakan tujuan tertentu, memfokuskan perubahan pada potensi sosial ekonomi yang berdasarkan pada kreatifitas dan intuisi individu Mengingat orang yang kreatif dan instuitif dikenal menyukai lingkungan kerja yang memberikan independensi dan otonomi yang tinggi. Sementara itu jiwa kewirausahaan juga berkait dengan pengambilan resiko, yang mengacu pada kemauan aktif untuk mengejar peluang. Resiko perlu diperhitungkan dan wirausaha secara objektif harus mengidentifikasikan faktor-faktor resiko dan sumber daya yang ada serta secara sistematis mengelola faktor-faktor ini. Dimensi ketiga kewirausahaan adalah proaktif melihatnya sebagai bagian sifat assertif, sementara Minzberg melihat bahwa kewirausahaan sebagai pengambil risiko dan melakukannya, daripada sekedar bereaksi terhadap lingkungannya (Erni Unggul, 1998). Implementasinya: (a) Memutuskan apakah dalam hal inovasi, organisasi mengikuti pesaing atau tidak, (b) Menyukai apa yang telah lalu atau pertumbuhan, inovasi dan pengembangan, (c) Mencoba bekerjasama dengan pesaing atau tidak, dan (d) Proaktif juga berkaitan dengan implementasi, melakukan apapun yang dilakukan untuk membawa konsep kewirausahaan pada pelaksanaan. Menurut Rambat Lupiyoadi, (2004) kewirausahaan akan dipermudah apabila dapat dilakukan: (a) Rentang kendali tetap dipertahankan secara luas, (b) Manajer memberikan seluruh visi dan arah strategi sambil mendelegasikan tanggungjawab dan wewenang inovasi kepada individu yang lebih rendah, (c) Individu dan tim ini diberi kebijakan operasional yang nyata pada saat pengembangan dan pengujian konsep dan gagasan baru, (d)
Kamunikasi terbuka, dimana setiap karyawan dapat secara langsung berinteraksi dengan karyawan lainnya baik secara formal maupun informal pada saat yang tepat. Menurut Sam Ariyanto, (2008), kewirausahaan mengacu pada perilaku yang meliputi: (a) Pengambilan inisiatif, (b) Mengorganisasi dan mengorganisasi kembali mekanisme sosial dan ekonomi untuk mengubah sumber daya dan situasi pada perhitungan praktis, (c) Penerimaan terhadap resiko dan kegagalan. Selanjutnya ia juga menjelaskan bahwa terdapat empat hal yang harus dimiliki oleh seorang wirausahawan, (d) Proses berkreasi, yakni mengkreasikan sesuatu yang baru dengan menambahkan nilainya. Pertambahan nilai ini tidak hanya diakui oleh wirausahawan semata namun juga audiens yang akan menggunakan hasil kreasi tersebut, (e) Komitmen yang tinggi terhadap penggunaan waktu dan usaha yang diberikan. Semakin besar fokus dan perhatian yang diberikan dalam usaha ini maka akan mendukung proses kreasi yang akan timbul dalam kewirausahaan, (f) Memperkirakan resiko yang mungkin timbul. Dalam hal ini resiko yang mungkin terjadi berkisar pada resiko keuangan, fisik dan resiko sosial, (g) Memperoleh reward. Dalam hal ini reward yang terpenting adalah independensi atau kebebasan yang diikuti dengan kepuasan pribadi. Sedangkan reward berupa uang biasanya dianggap sebagai suatu bentuk derajat kesuksesan usahanya. Sementara menurut Meredith dalam Suryana (2001) ciri-ciri wirausahawan dapat ditabulasikan sebagai berikut: 
Tabel 1. Ciri-ciri Wirausahawan

\begin{tabular}{|c|c|c|}
\hline No & Ciri-ciri & Keterangan \\
\hline 1. & Percaya diri & $\begin{array}{ll}\text { 1. } & \text { Bekerja penuh } \\
\text { keyakinan } \\
\text { 2. }\end{array}$ \\
\hline 2. & $\begin{array}{l}\text { Berorientasi } \\
\text { pada tugas dan } \\
\text { hasil }\end{array}$ & 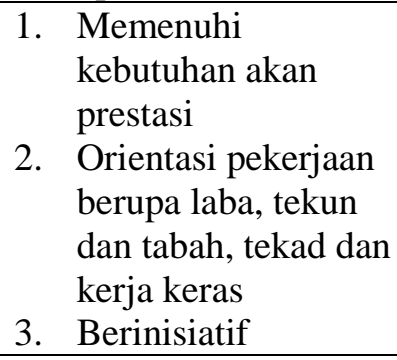 \\
\hline 3. & $\begin{array}{l}\text { Pengambil } \\
\text { resiko }\end{array}$ & 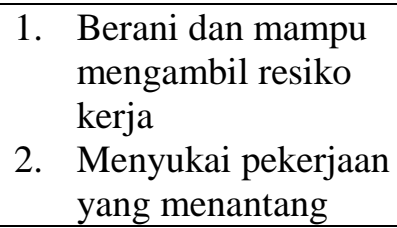 \\
\hline 4. & Kepemimpinan & $\begin{array}{ll}\text { 1. } & \text { Bertingkah laku } \\
\text { sebagai pemimpin } \\
\text { yang terbuka } \\
\text { terhadap saran dan } \\
\text { kritik }\end{array}$ \\
\hline 5. & $\begin{array}{l}\text { Berpikir } \\
\text { kearah yang } \\
\text { asli }\end{array}$ & $\begin{array}{ll}\text { 1. Kreatif dan inovatif } \\
\text { 2. } \\
\begin{array}{l}\text { Luwes dalam } \\
\text { melaksanakan } \\
\text { pekerjaan }\end{array} \\
\text { 3. } \\
\text { Mempunyai banyak } \\
\text { sumber daya } \\
\text { 4. } \begin{array}{l}\text { Serba bisa dan } \\
\text { berpengetahuan luas }\end{array} \\
\end{array}$ \\
\hline 6. & Keorisinilan & $\begin{array}{l}\text { 1. Berfikiran menatap } \\
\text { ke depan } \\
\text { 2. Perspektif }\end{array}$ \\
\hline
\end{tabular}

(Purbayu Budi Santoso, 2009) mengatakan bahwa mata pelajaran kewirausahaan sekarang ini perlu diberikan kepada semua peserta didik. Demikian juga kalau memungkinkan setiap pelajaran, di masukkan unsur kewirausahaan yang di dalamnya terkandung kreativitas, inovasi dan tidak takut kepada resiko, sehingga aspek praktik di lapangan menjadi prioritas utama. Beliau mencontohkan pendidikan pada masa lalu penuh dengan prakarya maupun muatan lokal. Implementasi integrasi kewirausahaan di SMK dapat dilakukan dengan bermacam-macam strategi dengan melihat kondisi siswa serta lingkungannya. Prinsip-prinsip implementasi harus masih dalam kerangka: (a) Tidak mengubah sistem pendidikan yang berlaku, (b) Tidak mengubah kurikulum, namun diperlukan penyiasatan kurikulum untuk diorientasikan pada kewirausahaan, (c) Etika sosio-religius bangsa dapat diintegrasikan dalam proses pendidikan,

Kompetensi dasar bidang produktif konstruksi batu dan beton pada standar kompetensi Melakukan Pekerjaan Batu Dan Beton: Membuat Komponen Bangunan Dari Semen dan topik kewirausahaan yang relevan adalah dapat dilihat pada table berikut:

Tabel 2. Hubungan Kompetensi Dasar Produktif dengan Topik Kewirausahaan

\begin{tabular}{|c|c|}
\hline $\begin{array}{l}\text { Kompetensi dasar } \\
\text { produktif batu dan } \\
\text { beton }\end{array}$ & $\begin{array}{c}\text { Topik kewirausahaan } \\
\text { yang relevan }\end{array}$ \\
\hline $\begin{array}{l}\text { - } \text { Mengidentifikasi } \\
\text { alat dan bahan } \\
\text { pembuatan produk } \\
\text { semen }\end{array}$ & $\begin{array}{ll}\text { - } & \text { Kesehatan dan } \\
\text { keselamatan kerja } \\
\text { - Komunikasi dan } \\
\text { kerjasama } \\
\text { - Sikap-sikap } \\
\text { wirausahawan } \\
\text { - Bekerja efektif dan } \\
\text { efisien } \\
\text { - Kualitas hasil }\end{array}$ \\
\hline $\begin{array}{l}\text { - Melaksanakan } \\
\text { pembuatan } \\
\text { komponen } \\
\text { bangunan } \\
\text { semen }\end{array}$ & $\begin{array}{l}\text { - } \text { Kesehatan dan } \\
\text { keselamatan kerja } \\
\text { - Komunikasi dan } \\
\text { kerjasama } \\
\text { - Sikap-sikap } \\
\text { wirausahawan } \\
\text { - Bekerja efektif dan } \\
\text { efisien } \\
\text { - Perawatan dan } \\
\text { penyimpanan } \\
\text { bahan } \\
\text { - Kualitas hasil } \\
\text { - Disiplin waktu }\end{array}$ \\
\hline
\end{tabular}


Kelompok Produktif meliputi sejumlah mata pelajaran yang dikelompokkan dalam Dasar Kompetensi Kejuruan dan Kompetensi Kejuruan. Materi pembelajaran Dasar Kompetensi Kejuruan dan Kompetensi Kejuruan disesuaikan dengan kebutuhan program keahlian untuk memenuhi standar kompetensi di dunia kerja. Sementara mata pelajaran Kewirausahaan termasuk dalam kelompok Adaptif. Hal ini berarti bahwa mata pelajaran Kewirausahaan diajarkan pada kelas 1, 2 dan 3 pada semua jurusan di SMK.Tugas guru dalam rangka pengembangan kurikulum KTSP adalah menjabarkan, menganalisis dan mengembangkan indikator, dan menyesuaikan Standar Kompetensi dan Kompetensi Dasar (SKKD) dengan karakteristik perkembangan peserta didik, situasi dan kondisi sekolah, serta kondisi dan kebutuhan daerah. Selanjutnya, mengemas hasil analisis SK-KD tersebut kedalam KTSP, yang di dalamnya mencakup Silabus dan Rencana Pelaksanaan Pembelajaran (RPP).

Penyusunan silabus, RPP Kewirausahaan, Standar Kompetensi dan Kompetensi Dasar serta Standard Kompetensi Lulusan (SKL) untuk mata pelajaran Kewirausahaan dapat dilihat pada table berikut:

Tabel 3. Standar Kompetensi Kompetensi Dasar Kewirausahaan

\begin{tabular}{|c|c|}
\hline $\begin{array}{c}\text { STANDAR } \\
\text { KOMPETENSI }\end{array}$ & KOMPETENSI DASAR \\
\hline $\begin{array}{l}\text { - Mengaktualisasi } \\
\text { kan sikap dan } \\
\text { perilaku } \\
\text { wirausaha }\end{array}$ & $\begin{array}{l}\text { - Mengidentifikasi sikap } \\
\text { dan perilaku wirausaha } \\
\text { - Menerapkan sikap dan } \\
\text { perilaku kerja prestatif } \\
\text { - Merumuskan solusi } \\
\text { masalah } \\
\text { - Mengembangkan } \\
\text { semangat wirausaha } \\
\text { - Membangun komitmen } \\
\text { bagi dirinya dan bagi } \\
\text { orang lain } \\
\text { - Mengambil resiko usaha } \\
\text { - Membuat keputusan } \\
\end{array}$ \\
\hline
\end{tabular}

\begin{tabular}{|c|c|}
\hline $\begin{array}{l}\text { - Menerapkan } \\
\text { jiwa } \\
\text { kepemimpinan }\end{array}$ & $\begin{array}{l}\text { - Menunjukkan sikap } \\
\text { pantang menyerah dan } \\
\text { ulet } \\
\text { - Mengelola konflik } \\
\text { - Membangun visi dan } \\
\text { misi usaha } \\
\end{array}$ \\
\hline $\begin{array}{l}\text { - Merencanakan } \\
\text { usaha } \\
\text { kecil/mikro }\end{array}$ & $\begin{array}{l}\text { - Menganalisis peluang } \\
\text { usaha } \\
\text { - Menganalisis aspek- } \\
\text { aspek pengelolaan usaha } \\
\text { - Menyusun proposal } \\
\text { usaha }\end{array}$ \\
\hline $\begin{array}{l}\text { - Mengelola } \\
\text { usaha } \\
\text { kecil/mikro }\end{array}$ & $\begin{array}{l}\text { - Mempersiapkan } \\
\text { pendirian usaha } \\
\text { - Menghitung resiko } \\
\text { menjalankan usaha } \\
\text { - Menjalankan usaha kecil } \\
\text { - Mengevaluasi hasil usaha }\end{array}$ \\
\hline
\end{tabular}

Silabus adalah suatu rencana yang mengatur kegiatan pembelajaran dan pengelolaan kelas, serta penilaian hasil belajar dari suatu mata pelajaran. Silabus ini merupakan bagian dari kurikulum sebagai penjabaran Standar Kompetensi dan Kompetensi Dasar ke dalam materi pembelajaran, kegiatan pembelajaran, dan indikator pencapaian kompetensi untuk penilaian hasil belajar. Dengan demikian pengembangan silabus ini minimal harus mampu menjawab pertanyaan sebagai berikut: kompetensi apakah yang harus dimiliki oleh peserta didik, bagaimana cara membentuk kompetensi tersebut, dan bagaimana cara mengetahui bahwa peserta didik telah memiliki kompetensi itu. Dengan berpedoman pada silabus diharapkan pengajar akan dapat mengajar lebih baik, tanpa khawatir akan keluar dari tujuan, ruang lingkup materi, strategi belajar mengajar, atau keluar dari sistem evaluasi yang seharusnya. Komponen silabus suatu mata pelajaran terdiri dari: (a) Identitas Mata pelajaran, dapat meliputi: nama mata pelajaran atau blok mata pelajaran, kode mata pelajaran, bobot mata pelajaran, semester, (b) Standar Kompetensi (SK), yang dibakukan 
sebagai hasil belajar materi pokok tertentu dalam satuan pendidikan, merupakan kompetensi bidang pengembangan dan materi pokok per satuan pendidikan per satu kelas yang harus dicapai peserta didik selama satu semester, (c) Kompetensi Dasar (KD), adalah rincian kompetensi dalam setiap aspek materi pokok yang harus dilatihkan kepada peserta didik sehingga kompetensi dapat diukur dan diamati. Kompetensi Dasar sebaiknya selalu dilakukan perbaikan dan pengayaan guna memenuhi keinginan pasar.

Rencana Pelaksanaan Pembelajaran (RPP) adalah rencana yang menggambarkan prosedur dan menajemen pembelajaran untuk mencapai satu atau lebih kompetensi dasar yang telah dijabarkan dalam silabus. RPP ini dapat digunakan oleh setiap pengajar sebagai pedoman umum untuk melaksanakan pembelajaran kepada peserta didiknya, karena di dalamnya berisi petunjuk secara rinci, pertemuan demi pertemuan, mengenai tujuan, ruang lingkup materi yang harus diajarkan, kegiatan belajar mengajar, media, dan evaluasi yang harus digunakan. RPP akan membantu pengajar dalam mengorganisasikan materi standar, serta mengantisipasi peserta didik dan masalahmasalah yang mungkin timbul dalam pembelajaran. Baik pengajar maupun peserta didik mengetahui dengan pasti tujuan yang hendak dicapai dan cara mencapainya. Seorang pengajar yang belum berpengalaman pada umumnya memerlukan perencanaan yang lebih rinci dibandingkan seorang pengajar yang sudah berpengalaman. Komponen RPP terdiri dari: (a) Kolom Identitas Mata Pelajaran, (b) Standar Kompetensi, (c) Kompetensi Dasar, (d) Indikator Pencapaian Kompetensi, (e) Tujuan
Pembelajaran, (f) Materi Ajar (Materi Pokok), (g) Materi/Kompetensi Prasyarat, (h) Alokasi Waktu, (i) Metode Pembelajaran, (j) Kegiatan Pembelajaran, (k) Penilaian dan (1) Sumber Belajar.

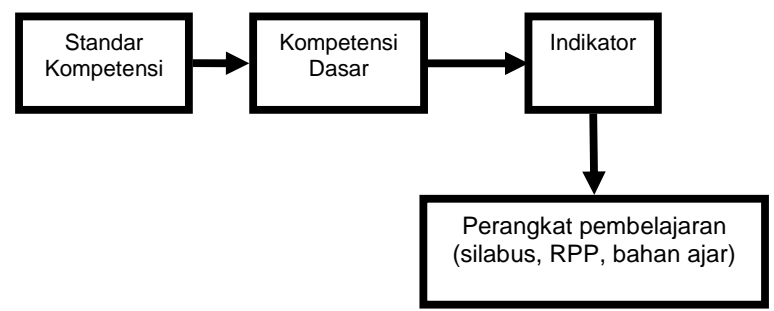

Gambar 1. Alur pengembangan bahan ajar (Sosialisasi KTSP, 2008)

Prinsip pengembangan bahan ajar (Sosialisasi KTSP, 2008) menyebutkan bahwa: (a) Mulai dari yang mudah untuk memahami yang sulit, dari yang kongkret untuk memahami yang abstrak, (b) Pengulangan akan memperkuat pemahaman, (c) Umpan balik positif akan memberikan penguatan terhadap pemahaman siswa, (d) Motivasi belajar yang tinggi merupakan salah satu faktor penentu keberhasilan belajar, (e) Mencapai tujuan ibarat naik tangga, setahap demi setahap, akhirnya akan mencapai ketinggian tertentu, (f) Mengetahui hasil yang telah dicapai akan mendorong siswa untuk terus mencapai tujuan. Sementara tujuan pengembangan bahan ajar (Sosialisasi KTSP, 2008) adalah: (a) Menyediakan bahan ajar yang sesuai dengan tuntutan kurikulum dengan mempertimbangkan kebutuhan siswa, yaitu bahan ajar yang sesuai dengan karakteristik dan lingkungan sosial siswa, (b) Membantu siswa dalam memperoleh alternatif bahan ajar, (c) Memudahkan guru dalam melaksanakan pembelajaran.

Pengintegrasian nilai-nilai kewirausahaan sejalan dengan konsep Kurikulum 2004 yang menekankan pada kemampuan melakukan 
(kompetensi) berbagai tugas dengan standar performansi tertentu, sehingga hasilnya berupa penguasaan seperangkat kompetensi tertentu, sebagai gabungan pengetahuan, keterampilan, nilai sikap dan minat sebagai hasil belajar yang refleksinya adalah berupa kebiasaan berpikir dan bertindak ekonomis ketika menghadapi masalah.

Pengintegrasian nilai - nilai kewirausahaan hendaknya memperhatikan potensi lokal daerah masing-masing, sesuai dengan lokasi/tempat siswa tinggal. Pertimbangan lain adalah heterogenitas latar belakang siswa, seperti kehidupan keluarga, sekolah, masyarakat, dan usia tingkat perkembangan siswa, yang pada gilirannya siswa akan memiliki jiwa berwirausaha dan memiliki kesadaran tinggi untuk mengaktualisasikan potensinya secara cerdas dalam kehidupan bermasayarakat. (http://118.98.213.22/ aridata_web/ puskur/ bab12wirausaha.doc diakses tanggal 26 Februari 2010)

Penanaman jiwa kewirausahaan memerlukan waktu lama. Pada usia yang masih muda, motivasi untuk berwiraswasta merupakan modal utama. Jiwa kewirausahaan dapat diprediksi dari seseorang yang memiliki kemampuan tersebut. Seseorang yang mempunyai pusat kendali diri, percaya kehidupan sepenuhnya dikendalikan dan ditentukan oleh faktor-faktor yang ada dalam dirinya misalnya kemauan atau motivasi yang kuat, kerja keras atau potensi-potensi positif lainnya.

Dari tahapan tersebut, guru harus melakukan inventarisasi agar proses belajar dapat berjalan sesuai dengan tujuan yang telah ditetapkan. Demikian pula untuk menumbuhkan kesiapan untuk menjadi wirausahawan pada siswa, guru perlu menginventarisasi kegiatan sejak belajar tahap generalisasi. Dari tahap ini lahirlah kinerja sebagai hasil dari proses belajar.

Penyisipan aspek kewirausahaan di SMK Bangunan saat ini sudah dilakukan meskipun belum sepenuhnya menganut pokok kewirausahaan yang sebenarnya. Siswa sudah dilibatkan dalam mengelola unit produksi, meskipun hanya sebatas dalam membuat benda kerja praktik yang layak jual, seperti: membuat dan merangkai tulangan kolom praktis, membuat kosen pintu-jendela dari kayu, membuat kursi taman dari praktik mengelas dan lain sebagainya. Namun dalam perkembangannya, siswa belum dibentuk kesiapannya sebagai seoarang yang akan menjadi wirausahawan. Siswa belum dilibatkan secara langsung dalam praktik menjualnya, sehingga proses ini belum mampu menumbuhkan jiwa entrepreneurship. Oleh karena ini untuk menumbuhkannya, perlu dirancang model pembelajaran yang terintegrasi dengan kewirausahaan dan diimplementasikan dalam proses pembelajaran dan latihan kewirausahaan yang sebenarnya.

Integrasi kewirausahaan dalam pembelajaran memiliki peran yang strategis dalam menyiapkan calon lulusan yang berdaya saing, siap kerja serta dapat mengubah paradigma bahwa lulusan dengan kemampuannya bagaimana mencari pekerjaan bergeser dengan berkat kemampuannya bagaimana menciptakan lapangan kerja. Oleh karenanya diperlukan formulasi integrasi kewirausahaan dalam pembelajaran guna mencapai peran tersebut. Di SMK Bangunan di Daerah Istimewa Yogyakarta belum ada implementasi kewirausahaan yang terintegrasi dalam pembelajaran. Adapun pembelajaran yang dimaksud adalah bidang produktif konstruksi batu dan beton. Industri 
yang bergerak di bidang konstruksi batu dan beton, mulai yang dikelola perseorangan maupun perusahaan banyak memberikan kesempatan siswa untuk bekerja setelah lulus nanti. Dari segi peluang, usaha pembuatan benda kerja bidang produktif kerja batu dan beton, seperti: batako merupakan salah satu alternatif untuk berwirausaha. Hal ini dikarenakan mudah untuk dilaksanakan, baik dari segi pengelolaan keuangan, tenaga kerja, proses produksi dan pemasarannya.

Dalam penyusunan bahan ajar terintegrasi kewirausahaan harus memperhatikan proses integrasi kewirausahaan pada mata pelajaran produktif dibawah ini:

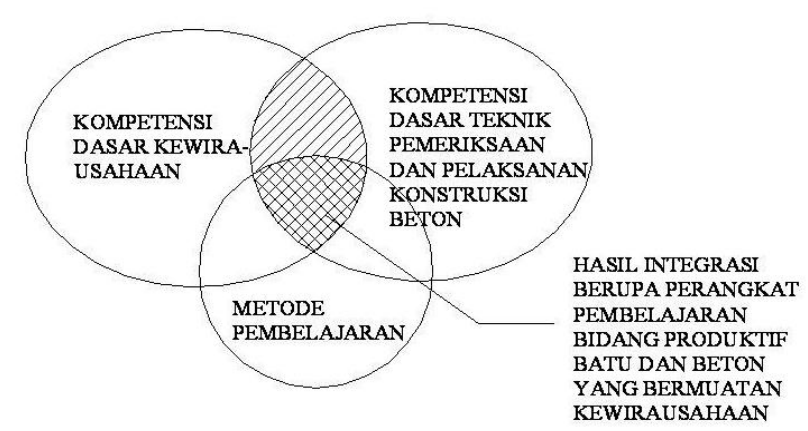

Gambar. 2. Proses integrasi kewirausahaan pada mata pelajaran produktif
Langkah-langkah integrasi kewirausahaan, antara lain: (1) melakukan identifikasi unsur kewirausahaan yang dikembangkan dalam kehidupan nyata yang dituangkan dalam bentuk kegiatan pembelajaran, (2) melakukan identifikasi pengetahuan, keterampilan, sikap dan nilai-nilai yang mendukung kewirausahaan, (3) mengklasifikasi dalam bentuk topik/tema dari mata pelajaran yang sesuai dengan kewirausahaan, (4) Melakukan identifikasi kompetensi dasar yang relevan untuk dimasuki kewirausahaan, (5) Menghasilkan kompetensi dasar ( materi pelajaran) yang sudah terintegrasi kewirausahaan. Dalam hal ini materi yang tersusun mengandung isi dari kewirausahaan meski hanya sedikit yang menyatu menjadi satu kesatuan yang utuh, (6) Membuat strategi pembelajaran dan alat evaluasi untuk mata pelajaran produktif batu dan beton yang terintegrasi kewirausahaan, (7) Membuat media pembelajaran yang sesuai, (8) Revisi menerus, (9) Uji coba di SMK dan merevisi secara keseluruhan.

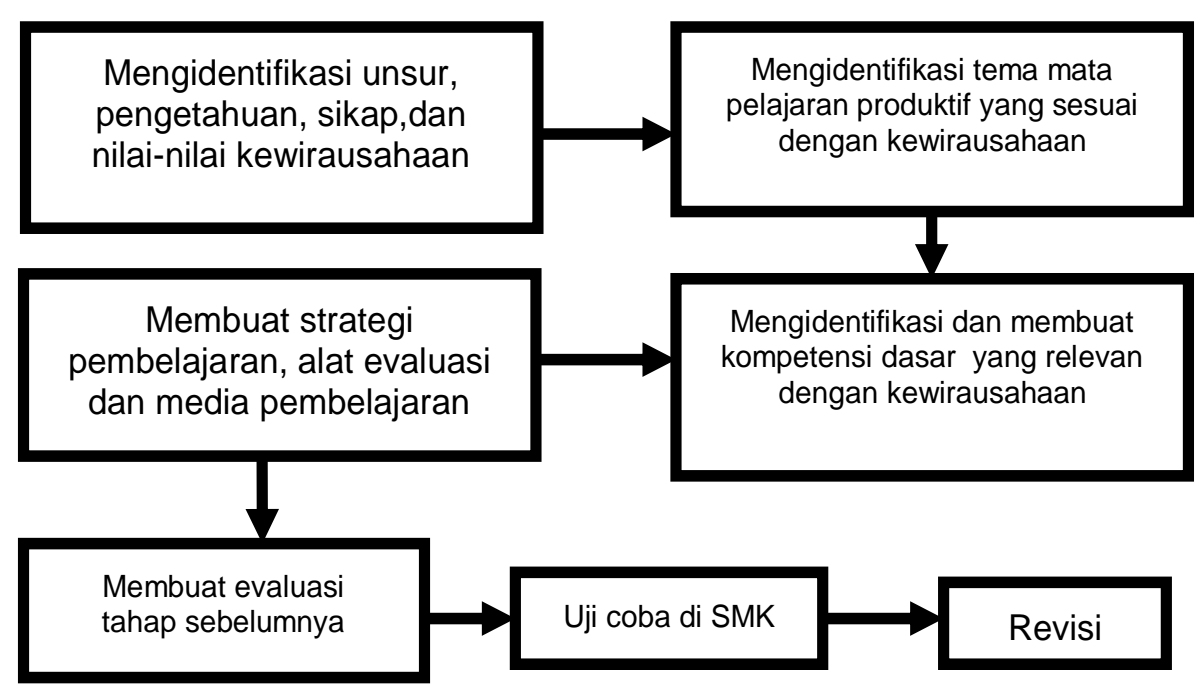

Gambar. 3. Tahapan integrasi kewirausahaan pada mata pelajaran produktif konstruksi batu dan beton. 
Pembuatan kerangka materi pembelajaran harus mempertimbangkan nilai - nilai kewirausahaan yang telah diajarkan pada SMK dengan memasukkan nilai kewirausahaan yang relevan pada setiap pokok materi, dalam hal ini materi yang terkandung dalam topik pembelajaran tidak terlalu luas dalam arti hanya poin-poin yang penting saja. Misalnya dalam pembelajaran pasangan batako

Tabel 4. Kompetensi yang akan dicapai dalam pembuatan batako dan relevansi topik kewirausahaan

\begin{tabular}{|c|c|}
\hline $\begin{array}{l}\text { Kompetensi yang akan dicapai } \\
\text { dalam pembuatan batako }\end{array}$ & Topik kewirausahaan \\
\hline Pembuatan Batako & $\begin{array}{l}\text { - Mengaktualisasikan sikap dan perilaku } \\
\text { wirausaha: } \\
\text { - Mengidentifikasi sikap dan perilaku } \\
\text { - } \text { wirausaha } \\
\text { - Merumuskan solusi masalah } \\
\text { - Mencanakan usaha kecil/mikro } \\
\text { - Menganalisis peluang usaha } \\
\text { - } \text { usaha } \\
\text { Menyusun proposal usaha }\end{array}$ \\
\hline
\end{tabular}

Kompetensi yang akan dicapai dalam pembuatan batako harus relevan dengan topik kewirausahaan yang diajarkan pada siswa Tingkat SMK. Dasar topik kewirausahaan yang direkomendasikan adalah, bahwa topik dipilih akan mempromosikan pendidikan kewirausahaan dalam bidang pendidikan kejuruan produktif konstruksi batu dan beton. Topik- topik tersebut dikategorikan dalam topik inti yang bersifat umum yang berkaitan dengan ilmu kewirausahaan serta hal- hal yang terkait dan topik kewirausahaan yang spesifik yang relevan dengan pendidikan kejuruan produktif konstruksi batu dan beton. Pendidikan kejuruan produktif konstruksi batu dan beton yang terintegrasi kewirausahaan bukan hanya menyangkut isi pelajaran tetapi juga meliputi proses belajar mengajar.

Pembagian waktu dalam melaksanakan praktik membuat batako terdiri dari 2 Kompetensi Dasar dan 6 kali tatap muka, 3 kali praktik dan 3 kali teori, setiap tatap muka teori terdiri 2 jam x 45 menit, tatap muka praktek 4 jam x 45 menit dalam hal ini tidak mengubah waktu yang ada dalam silabus konstruksi batu dan beton tetapi memaksimalkan waktu dari silabus produksi konstruksi batu dan beton yang ada. Adapun standar kompetensi kewirausahaan diambil pada poin 1 dan 3 ( lihat Tabel 4 hal 51) tetapi tidak semua kompetensi dasar akan dicapai mengingat keterbatasan waktu pembelajaran. Adapun kerangka materi batako yang terintegrasi kewirausahaan sebagai berikut: 
Tabel 5. Penyusunan kerangka materi batako yang terintegrasi kewirausahaan

\begin{tabular}{|l|l|}
\hline Materi batako yang terintegrasi kewirausahaan & \multicolumn{1}{|c|}{$\begin{array}{c}\text { Materi kewirausahaan yang relevan } \\
\text { dengan materi batako }\end{array}$} \\
\hline - Materi I Peluang Usaha Batako & - Pengamatan lingkungan usaha \\
- Latar belakang usaha batako & - Mengenal peluang usaha \\
- Kelebihan dan kekurangan usaha batako & Keberhasilan dan kegagalan \\
berwirausaha
\end{tabular}

Dalam pelaksanaan pengembangan materi ajar yang terintegrasi kewirausahaan, tidak semua prosedur pelaksanaan cara pembuatan batako dilakukan, hal ini dikarenakan mengingat pembagian waktu, dalam hal ini materi yang diajarkan dialokasikan 18 jam x 45 menit dengan pembagian waktu pembelajaran sebagai berikut:

Tabel 6. Pembagian Materi Pembelajaran dan Alokasi Waktu

\begin{tabular}{|l|l|l|}
\hline \multicolumn{1}{|c|}{ Materi } & \multicolumn{1}{|c|}{ Alokasi waktu } & Pertemuan ke- \\
\hline Materi I dan II & $\begin{array}{l}4 \mathrm{x} 45 \text { menit } \\
\text { (2 pertemuan teori) }\end{array}$ & 1 dan 2 \\
\hline $\begin{array}{l}\text { Materi II } \\
\begin{array}{l}\text { 1. praktek membuat batako } \\
\text { (2 pertemuan praktek) }\end{array}\end{array}$ & $\begin{array}{l}12 \mathrm{x} 45 \text { menit } \\
(3 \text { pertemuan praktek) }\end{array}$ & 3,4 dan 5 \\
$\begin{array}{l}\text { 2. praktek perawatan batako dan pengujian visual batako } \\
(1 \text { pertemuan praktek) }\end{array}$ & $\begin{array}{l}2 \times 45 \text { menit } \\
\text { (1 pertemuan teori) })\end{array}$ & 6 \\
\hline Materi III dan IV & \\
\hline
\end{tabular}

Dari penyusunan materi ajar diatas diharapkan akan memberikan stimulus bagi siswa untuk berwirausaha. Standar Kompetensi dan Kompetensi Dasar (SK-KD) silabus dapat dipadukan dengan nilai - nilai kewirausahaan sehingga dapat dilakukan pengembangan bahan ajar seperti dicantumkan diatas, Standar Kompetensi Melakukan Pekerjaan Batu Dan Beton Membuat Komponen Bangunan Dari Semen yang terdapat pada Mata Pelajaran 
praktek batu, plumbing dan kayu (Praktek Dasar), dapat diintegrasikan pada kompetensi dasarnya yaitu pelaksanaan pembuatan batako. Oleh karena itu, tepat apabila ke depan nanti tambahan materi ajar proses pembuatan dimasukkan ke dalam kurikulum baru agar terdapat nilai- nilai integrasi kewirausahaan di bidang konstruksi batu dan beton di dalam pembelajaran.

\section{KESIMPULAN}

Pengembangan Bahan Ajar Terintegrasi Kewirausahaan Bidang Produktif Konstruksi Batu dan Beton dapat menumbuhkan kesiapan siswa dalam berwirausaha. Hal ini tercermin: (1) Pelaksanaan standar kompetensi dan kompetensi dasar (SK-KD) didalam silabus Produktif Konstruksi Batu dan Beton dapat diintegrasikan dengan kewirausahaan. (2) Bentuk integrasi kewirausahaan pada bidang produktif konstruksi batu dan beton untuk menumbuhkan kesiapan siswa berwirausaha berupa penyusunan bahan ajar berwirausaha batako, yaitu pengembangan bahan ajar yang didalamnya dipadukan dengan nilai - nilai kewirausahaan, sehingga terjadi internalisasi dan personalisasi nilai - nilai kewirausahaan tersebut serta dapat dipahami dan dilaksanakan oleh peserta didik secara konsisten di dalam pembelajaran. (3) Pengembangan Rencana Pelaksanaan Pembelajaran bidang produktif konstruksi batu dan beton yang telah terintegrasi kewirausahaan dengan memasukkan metode pembelajaran mampu membuat siswa aktif dalam kegiatan pembelajaran sehingga mampu membentuk jiwa siswa untuk berwirausaha.

\section{DAFTAR PUSTAKA}

Arianto Sam. (2009). Pengertian Kewirausahaan. Artikel. Diakses dari http://sobatbaru.blogspot.com/ Diakses pada tanggal 6 mei 09

Depdiknas. (2003). Undang-undang RI Nomor 20, Tahun2003, tentang Sistem Pendidikan Nasional.

Depdiknas. (2005). Rencana Strategis Departemen Pendidikan Nasional tahun 2005-2009: Menuju Pembangunan Pendidikan Nasional Jangka Panjang 2025. Jakarta: Departemen Pendidikan Nasional.

Depdiknas, (2006). Peraturan Menteri Pendidikan Nasional No 22 Tahun 2006, tentang Standar Isi.

Depdiknas. (2009). Diterapkan 2010-2011 Kurikulum Berbasis Kewirausahaan. Jakarta: Jurnalnet.com, diakses pada tanggal 11 Oktober 2010 dari http://jurnalnasional.com/show/newspape r/03/11/2009-07:24 WIB/

Erni Ungul. (2009). Modul Pengantar Kewirausahaan. Artikel. Diakses dari http://www.poltektegal.ac.id. pada tanggal 6 Mei 2009.

Kasmir. (2007). Kewirausahaan, Jakarta : PT Raja Grafindo Perkasa.

Kebijakan Umum Direktorat Pembinaan SMK. (2010). Diakses pada tgl 22 November 2010 dari http://www2.ilmci.com/?p=1294

Muhamad Nuh. (2009). Kurikulum Berbasis Kewirausahaan Diterapkan 2010. Diakses pada tgl 26 November 2010 dari: http://www.endonesia.com/mod.php?mo $\mathrm{d}=$ publisher\&op=viewarticle $\& \mathrm{cid}=40 \& \mathrm{ar}$ tid $=4596$

Purbayu Budi Santoso. (2009). "Urgensi Pendidikan Kewirausahaan. Artikel. Diakses dari http://www.wawasandigital.com. Pada tanggal 6 Mei 2009.

Rhenald Khasali, (2010). Wirausaha Mandiri, Menggiat Jiwa Entrepreneur dari Kampus. Diakses pada 19 November 2010 dari http://spiritbisnis.com/news/2010/06/wirausahamandiri-menggiat-jiwa-entrepreneurdari-kampus/ 
Suyanto, (2006), Dinamika Pendidikan Nasional [Dalam Percaturan Dunia Global], PSAP Muhammadiyah, Jakarta.

Suyanto. (2009). Pembangunan Pendidikan SMK. Jakarta: Departemen Pendidikan Nasional, Direktorat Jenderal Manajemen Pendidikan Dasar dan Menengah.

Wiedy Murtini. (2009). Kewirausahaan Pendekatan Succes Story. Surakarta: Sebelas Maret University Press.
Workshop Pendidikan Kewirausahaan Di SMK. (2010). Diakses pada tgl 22 November 2010.

Dari http://www2.ilmci.com/?p=1312.

http://ruangjeda.blogspot.com/2010/02/pendidika n-kewirausahaan-smk.html. (2010). Pendidikan kewirausahaan \& SMK: Kesalahkaprahan strategi terhadap visi Depdiknas. Diakses pada 20 November 2010.

http://wirausahaumy.blogspot.com. Diakses tanggal 3 Mei 2009. 
